\title{
Entre o dito e o feito: a gestão da diversidade na "Terra das Culturas Diversificadas"
}

\author{
Between said and done: managing diversity in the "Land of Diversified Culltures" \\ Entre dicho y hecho: gestionar la diversidad en la "Tierra de las Culturas Diversificadas"
}

Recebido: 16/09/2021 | Revisado: 20/09/2021 | Aceito: 24/09/2021 | Publicado: 26/09/2021

Edi Branco da Silva

ORCID: https://orcid.org/0000-0001-8796-9815 Universidade Regional do Noroeste do Estado do Rio Grande do Sul, Brasil E-mail: edybranco@yahoo.com.br

Adriane Fabricio

ORCID: https://orcid.org/0000-0002-3508-2769

Universidade Federal de Santa Maria, Brasil E-mail: adrianefabricio@yahoo.com.br

Fabiana Zanardi

ORCID: https://orcid.org/0000-0003-1185-8232 Universidade Regional do Noroeste do Estado do Rio Grande do Sul, Brasil E-mail: fab.zan@hotmail.com

Airton Adelar Mueller

ORCID: https://orcid.org/0000-0001-6270-5856

Universidade Regional do Noroeste do Estado do Rio Grande do Sul, Brasil E-mail: airton.mueler@unijui.edu.br

\begin{abstract}
Resumo
O discurso e a prática da incorporação da diversidade nas organizações nem sempre conciliam o respeito à diferença com igualdade de oportunidades. Diante disso, este artigo tem como objetivo principal analisar práticas e discursos quanto à gestão da diversidade das maiores organizações de Ijuí/RS, "a Terra das Culturas Diversificadas". Trata-se de um estudo de caso, operacionalizado com base em métodos quantitativos e qualitativos. Primeiramente aplicou-se às 20 maiores empresas de Ijuí o questionário do "Perfil Social, Racial e de Gênero das 500 Maiores Empresas do Brasil”, elaborado pelo Instituto Ethos. Tal instrumento, já validado em pesquisas anteriores, busca avaliar como as organizações estão no que se refere à gestão da diversidade no âmbito de suas políticas internas. Em seguida, realizouse 37 entrevistas com gestores e representantes dos demais colaboradores. Estes últimos foram divididos em: minorias, representando os grupos que constituem a diversidade aqui em estudo (Pcds, negros, mulheres e pessoas com mais de 45 anos) e não minorias, representando os demais funcionários. A pesquisa revelou que as organizações não investem em políticas de diversidade. Alguns gestores entrevistados reconhecem que as organizações têm procurado a inserção de pessoas com diferentes perfis, no entanto, reconhecem que a validade dessa ação é ameaçada quando os indivíduos não depositam crédito na diversidade e quando há falta de oportunidades de ascensão e de reconhecimento. Na percepção das minorias as organizações não possuem uma cultura inclusiva que possibilite práticas de pertencimento. A transformação nessa agenda requer o rompimento de atitudes preconceituosas e discriminatórias no ambiente corporativo.
\end{abstract}

Palavras-chave: Pessoas com Deficiência (PCD); Negros; Mulheres; Envelhecimento; Desenvolvimento.

\begin{abstract}
The discourse and practice of incorporating diversity into organizations do not always reconcile respect for difference with equal opportunities. Therefore, this article aims to analyze practices and discourses regarding the management of diversity in the largest organizations in Ijuí/RS, "the Land of Diversified Cultures". It is a case study, operationalized based on quantitative and qualitative methods. First, the questionnaire of the "Social, Racial and Gender Profile of the 500 Largest Companies in Brazil" was applied to the 20 largest companies in Ijuí, prepared by the Ethos Institute. This instrument, which has already been validated in previous research, seeks to assess how organizations are dealing with diversity management within the scope of their internal policies. Then, 37 interviews were carried out with managers and representatives of other employees. The latter were divided into: minorities, representing the groups that constitute the diversity under study (Pcds, blacks, women and people over 45) and non-minorities, representing the other employees. The survey revealed that organizations do not invest in diversity policies. Some managers interviewed recognize that organizations have sought to include people with different profiles, however, they recognize that the validity of this action is threatened when individuals do not credit diversity and when there is a lack of opportunities for advancement and recognition. In the perception of minorities, organizations do not have an inclusive culture that allows for belonging practices. The transformation of this agenda requires the breaking of prejudiced and discriminatory attitudes in the corporate environment.
\end{abstract}

Keywords: Disabled people; Blacks; Women; Aging; Development. 


\begin{abstract}
Resumen
El discurso y la práctica de incorporar la diversidad en las organizaciones no siempre concilian el respeto por la diferencia con la igualdad de oportunidades. Por tanto, este artículo tiene como objetivo analizar prácticas y discursos sobre la gestión de la diversidad en las mayores organizaciones de Ijuí / RS, "la Tierra de las Culturas Diversificadas". Es un estudio de caso, operacionalizado con base en métodos cuantitativos y cualitativos. En primer lugar, se aplicó el cuestionario "Perfil social, racial y de género de las 500 mayores empresas de Brasil" a las 20 mayores empresas de Ijuí, elaborado por el Instituto Ethos. Este instrumento, que ya ha sido validado en investigaciones anteriores, busca evaluar cómo las organizaciones están lidiando con la gestión de la diversidad en el ámbito de sus políticas internas. Luego, se realizaron 37 entrevistas con gerentes y representantes de otros empleados. Estos últimos se dividieron en: minorías, que representan a los colectivos que constituyen la diversidad en estudio (Pcds, negros, mujeres y mayores de 45 años) y no minorías, que representan al resto de empleados. La encuesta reveló que las organizaciones no invierten en políticas de diversidad. Algunos directivos entrevistados reconocen que las organizaciones han buscado incluir a personas con diferentes perfiles, sin embargo, reconocen que la vigencia de esta acción se ve amenazada cuando los individuos no dan crédito a la diversidad y cuando faltan oportunidades de avance y reconocimiento. En la percepción de las minorías, las organizaciones no tienen una cultura inclusiva que permita prácticas de pertenencia. La transformación de esta agenda requiere la ruptura de actitudes prejuiciosas y discriminatorias en el entorno empresarial.
\end{abstract}

Palabras clave: Personas con Discapacidad (PCD); Negros; Mujeres; Envejecimiento; Desarrollo.

\title{
1. Introdução
}

O estudo propõe estimular a adoção de ações em favor da inclusão e do respeito a segmentos com histórico de vulnerabilidades e desvantagens na sociedade. São analisados dados em relação a sexo, cor ou raça, deficiência e idade, considerando escolaridade na distribuição de oportunidades na hierarquia interna das organizações. O repertório de questões apresentadas neste constructo, dialoga intensamente com a proposta do desenvolvimento, considerando o ponto de partida da articulação entre cultura, diversidade e desenvolvimento.

A gestão da diversidade da força de trabalho, enquanto tema de estudo no contexto das organizações, é ainda muito recente e controversa. Cox e Blake (1991) foram os primeiros a defender as vantagens da gestão da diversidade sob a perspectiva do desempenho econômico. A literatura acadêmica brasileira ainda é incipiente (Bento, 2000); o pioneiro trabalho acadêmico sobre a gestão da diversidade no Brasil, apresentado por Fleury (2000), defende que a valorização da gestão da diversidade teria um aspecto altamente positivo por representar iniciativas promissoras de inclusão social.

A questão da diversidade tem se consolidado na pauta organizacional em todo o mundo, principalmente em razão das diferenças na força de trabalho. Aspectos como gênero, etnia, orientação sexual, idade, crença religiosa ou limitações físicas, por exemplo, assinalam a heterogeneidade (Alves \& Galeão-Silva, 2004; Fleury, 2000; Nkomo \& Cox 1993), demandando práticas que harmonizem lucro e justiça social (Robbins \& Coulter, 1998).

Estudos evidenciam as consequências diretas associadas a um clima construtivo de diversidade. Essas vantagens incluem melhor desempenho dos funcionários e da organização (Mckay \& Avery, 2015). Pesquisas adicionais também descobriram que um estilo de liderança transformacional é influente para ajudar a integração social das minorias culturais e a solução criativa de problemas dentro das organizações (Malik \& Singh, 2017). Estudos futuros devem explorar ainda mais a incorporação da diversidade. No entanto, a nova liderança inclusiva deve transcender os discursos corporativos.

A gestão da diversidade tornou-se uma prática bastante difundida no contexto nacional e norte-americano. Porém, como apontam as obras mais gerencialistas consultadas, sua implementação não é fácil. Dentre os principais obstáculos apontados estão o ceticismo dos próprios funcionários das organizações em relação aos programas e sua efetividade; uma atitude preconceituosa em relação a colegas ou líderes que são beneficiários desses programas; e as dificuldades em modificar rotinas de gestão de recursos humanos para incluir a questão da diversidade (Austin, 1997; Milliken \& Martin, 1996; Wise \& Tschirhart, 2002).

Com base nos princípios da Convenção $\mathrm{n}^{\circ} 111$ da Organização Internacional do Trabalho (OIT), sobre a discriminação em matéria de emprego e profissão, ratificada pelo Brasil em 26 de novembro de 1965, a educação profissional 
vem atuando com a finalidade de promover a igualdade de oportunidades, tornando o mercado de trabalho isento de todas as formas de discriminação. Contudo, uma das grandes dificuldades para o enfrentamento das práticas discriminatórias no trabalho refere-se ao fato das práticas e falas não serem assumidas culturalmente pela sociedade brasileira.

Ocorre que a eliminação das desigualdades de oportunidades no trabalho, a que estão submetidos os grupos considerados "diversos" aos padrões socioculturais dominantes, se configura, primeiramente, por meio do respeito à diversidade, o que implica a não discriminação, e, a seguir, pela implementação de programas de promoção de igualdade de oportunidades no mercado de trabalho. As organizações estão entre os principais promotores de oportunidades de trabalho e de realização profissional. Por outro lado, existem dados expressivos da permanência de práticas discriminatórias no âmbito das relações de trabalho no Brasil. Exatamente porque oferecem as oportunidades, as organizações estão especialmente sujeitas ao protagonismo de situações de discriminação. A partir dessa compreensão, a criação de políticas e programas de incentivo à inclusão, com oportunidades iguais para todos os níveis, políticas de bonificação e planejamento de carreira para todos os cargos, são ações com as quais as organizações deve se preocupar. É nesta mesma perspectiva de investigação que o presente artigo busca descrever as incoerências entre o dito e o feito.

Certamente, a possibilidade de debater e conhecer os grupos minoritários pode oferecer uma base para construir uma compreensão do entrelaçamento dos componentes sociais. Além do mais, a administração das organizações está intrinsecamente ligada à gestão da diversidade, que pode referir-se a competências, habilidades, gênero, experiência, idade, origem social ou cultura. $\mathrm{O}$ desafio dos gestores é conseguir uma inclusão organizacional que não anule o potencial das diferenças (Ethos, 2016). Esteves (1999, p.7) enfatiza que "não há consciência da discriminação nas organizações e talvez por isso, mais ou menos, 'todos se parecem'. Não é incomum as pessoas verem nessa questão da diversidade a importação de um problema que não é nosso". Nem mesmo para as organizações multinacionais, com larga experiência em programas de diversidade, a questão da discriminação parece fazer parte das prioridades do cotidiano. Portanto, a questão de pesquisa que orienta este estudo é: como o tema gestão da diversidade vem sendo incorporado nas organizações do município de Ijuí/RS, "a Terra das Culturas Diversificadas"? Contudo, espera-se que a leitura deste estudo contribua para a construção de reflexões sobre a valorização de todas as culturas, com a justiça social, racial e de gênero.

\section{A Incorporação da Diversidade no Mundo Organizacional}

Ao mesmo tempo em que o tema diversidade pode ser abrangente a ponto de considerar todas as particularidades de um indivíduo, dependendo da capacidade que se tem de separar os grupos dentro de uma sociedade, a sua definição pode ficar bastante restrita, considerando-se apenas um grupo formado por maioria e outro formado pelas minorias. A variedade de conceitos reflete a renovação constante neste campo de estudo e também a diversidade de pontos de vista existentes.

Nkomo e Cox Jr. (2010, p. 333) explicam que não há consentimento em vista das muitas formas de diversidade em que os estudos organizacionais são desenvolvidos; mesmo assim defendem sua conceituação para o termo diversidade, como "um misto de pessoas com identidades grupais diferentes dentro do mesmo sistema social". Cox (1991) entende que a fonte dessas diferenças não está nas dimensões em si, mas no significado que os grupos atribuem a elas, ou seja, às características que os diferenciam, sejam elas visíveis ou não.

A partir dessa visão entende-se a diversidade como uma variável dependente da cultura e como um conceito discutível, pois somente se origina a partir do momento em que há uma dicotomia entre pelo menos dois grupos, onde um se enxerga diferente do outro a partir de algumas dimensões (raça, gênero, etnia e nacionalidade), mas não pelas dimensões em si, mas pelo significado e valor cultural que elas atribuem ao grupo. "As diferenças entre os indivíduos ocorrem a partir das vantagens econômicas e de poder que uns obtiveram em relação aos outros no decorrer da história” (Cox, 1993, p.6). Ao 
corroborar com o conceito de diversidade cultural a partir das diferentes representações grupais em um mesmo sistema, Cox (1993) entende que embora no Brasil as diferenças entre os grupos majoritário e minoritário não sejam explícitas, elas existem:

[...] embora o povo brasileiro valorize sua origem diversificada, e goste de se imaginar como uma sociedade sem preconceitos de raça ou de cor, ele reflete na realidade uma sociedade estratificada, em que o acesso às oportunidades educacionais e às posições de prestígio no mercado de trabalho é definido pelas suas origens econômicas e raciais (Fleury, 2000, p.19).

Quando se fala de minorias tenta-se pelo menos distinguir o simples conceito jurídico que diz respeito à formação da vontade política pelo procedimento do voto, do conceito sociológico que é o que mais interessa para análise da gestão da diversidade nas organizações. Para Moreira (1984), "um grupo que se distingue da sociedade global pela etnia, nacionalidade, religião ou língua, acrescentando o sentimento de identidade dos que lhe pertencem e condutas discriminatórias dos que lhe são exteriores". Ainda segundo o autor, não se encontra um conceito operacional útil que não faça referência ao poder, visto que o conceito sociológico de minoria não está realmente ligado a uma expressão numérica relativa.

A palavra "minoria", não se refere a um número menor de pessoas, à sua quantidade, mas sim a uma situação de desvantagem social. Ou seja, apesar de muitas vezes coincidir de um grupo minoritário ser realmente a menor parte da população, não é o fator numérico o essencial para que uma população possa ser considerada uma minoria. São as relações de dominação entre os diferentes subgrupos na sociedade e o que os grupos dominantes determinam como padrão que delineiam o que se entende por minoria em cada lugar. Comportamentos discriminatórios e preconceituosos também costumam afetar os grupos minoritários. É importante frisar que não há consenso absoluto quanto ao conceito de minorias. Alguns autores estreitam a definição, ao reduzir os tipos de características que podem definir uma minoria. Outros, afirmam que o termo não possui uma definição única e que sua intenção sempre dependerá do autor que está utilizando. Nesta pesquisa, aborda-se o conceito de minorias no sentido mais amplo, conforme a definição do sociólogo Mendes Chaves (1971):

A palavra minoria se refere a um grupo de pessoas que de algum modo e em algum setor das relações sociais se encontra numa situação de dependência ou desvantagem em relação a um outro grupo, majoritário, ambos integrando uma sociedade mais ampla. As minorias recebem quase sempre um tratamento discriminatório por parte da maioria (Chaves, 1971, p. 149).

Se vislumbrada pelo âmbito social e individual a gestão da diversidade é compreendida como aliada para a redução de conflitos decorrentes de ambientes multiculturais. Se olhada pelo âmbito organizacional, observa-se o entendimento de que ela é capaz de trazer vantagem competitiva e valor ao negócio (Alves \& Galeão-Silva, 2004; Fleury, 2000; Cox JR, 1993). Acreditava-se que regras administrativas prescritivas poderiam ser aplicadas e, independente do contexto interno, os resultados seriam os mesmos. No entanto, sabe-se que fatores culturais, como crenças, atitudes e valores, influenciam na maneira como os integrantes interpretam as estratégias e regras organizacionais. Portanto, o comportamento e resultados organizacionais serão diferentes na medida em que seus funcionários forem culturalmente diferentes (Motta, 1996). Thomas Jr (1990) indica que o objetivo maior de um programa de gestão da diversidade não é assimilar as minorias dentro da cultura dominante da maioria, mas sim, criar uma cultura heterogênea dominante. Para o autor a cultura corporativa é um tipo de árvore:

Suas raízes são suposições sobre a empresa e o mundo. Seus galhos, folhas e sementes são comportamento. Você não pode mudar as folhas sem mudar as raízes e não pode cultivar pêssegos em um carvalho. Ou melhor, com o enxerto adequado, você pode cultivar pêssegos em um carvalho, mas eles saem muito como bolotas duras e não muito saborosas de comer. Portanto, se você deseja cultivar pêssegos, deve certificar-se de que as raízes das árvores sejam amigáveis (Thomas JR, 1990, p. 12). 
Ampliando a visão de Cox (1991), os autores Thomas e Ely (1996) enfatizam que a gestão da diversidade precisa ir além da questão de aumentar o número de empregados com afiliações de identidades diferentes em toda a organização ou de propiciar uma qualificação para eles. Eles acreditam que esse pressuposto é limitado e limitante, isso porque, eles entendem que os chamados "diversos", não trazem para a organização somente informações, quando admitidos, mas trazem importantes e competitivos conhecimentos e perspectivas sobre como fazer trabalho, como desenhar processos, como atingir objetivos, estruturar tarefas, criar times efetivos, comunicar ideias e conduzi-las.

\section{Metodologia}

Para a realização desta pesquisa, optou-se em seguir o paradigma interpretativista. No entendimento de Burrel e Morgan (1979), o mundo social tem status ontológico e precário e a realidade social não existe em termos concretos, mas é um produto de experiências subjetivas e intersubjetivas dos indivíduos. Quanto ao método que proporciona a base lógica da investigação, opta-se pela fenomenologia. Nessa perspectiva, o paradigma interpretativista, mediante a fenomenologia como método de pesquisa, aponta caminhos e alternativas concretas nesse direcionamento. Aqui, destaca-se a vertente fenomenológica como alternativa para os estudos da Gestão da Diversidade, encontra-se acomodada dentro do contexto do paradigma interpretativista.

Quanto à natureza trata-se de uma pesquisa social aplicada. Quanto ao nível e procedimento, refere-se num primeiro momento, à pesquisa exploratória, num segundo momento, propõe-se a pesquisa descritiva. Sob o ponto de vista da abordagem do problema, a pesquisa situa-se nas medições quantitativa e qualitativa. Concomitante a isto, a utilização da triangulação, no sentido complementaridade e amplitude.

Os sujeitos da pesquisa são compostos pelos seguintes segmentos: Pessoas com Deficiência (PcD), Mulheres, Negros e Pessoas com mais de 45 anos. Considera-se o ano base 2018, o Balanço Social dos anos de 2014 a 2018. A pesquisa da evolução dos grupos minoritários em cargos de chefia foi realizada por meio de cálculos da estatística descritiva. Definiu-se os seguintes critérios de inclusão e exclusão:

a) Critérios de inclusão: organização com 100 (cem) ou mais empregados; aceitar participar do estudo; preferencialmente organizações da amostra que divulgam os dados referente à Pessoas com Deficiência (PcD), Mulheres, Negros e Pessoas com mais de 45 anos em seu BS e/ou RA.

b) Critérios de exclusão: organização com menos de 100 (cem) empregados; não aceitar participar do estudo; titubear em fornecer as informações referente à Pessoas com Deficiência (PcD), Mulheres, Negros e Pessoas com mais de 45 anos.

Quanto à amostra optou-se por utilizar a técnica de amostragem não probabilística do tipo intencional, decidiu-se pelo critério da Lei 8.213 de 24 de julho de 1991, que representa grande avanço na questão relacionada à empregabilidade das pessoas com deficiência. Para tanto, as previsões da Lei ${ }^{\circ}$ 8.213/911 estabelecem que as organizações cumpram cotas relativas à contratação das pessoas com deficiência em relação direta com o número de empregados não deficientes e cria a obrigatoriedade para as organizações privadas de contratação de pessoas com deficiência e de reabilitados do INSS estabelecendo cotas nos seguintes termos:

Art. 93. A empresa com 100 (cem) ou mais empregados está obrigada a preencher de $2 \%$ (dois por cento) a 5\% (cinco por cento) dos seus cargos com beneficiários reabilitados ou pessoas portadoras de deficiência, habilitadas, na seguinte proporção:

I - Até 200 Empregados. $2 \%$

${ }^{1}$ Segundo dados aceitos e divulgados pela ONU, $10 \%$ da população mundial tem algum tipo de deficiência. No Brasil, conforme dados do último Censo do IBGE, esse percentual é maior. Logo, empregar percentual de 5\% para a reserva de vagas significa desconsiderar os dados da ONU. 


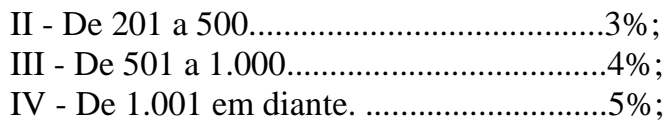

A partir dessa amostra, buscou-se identificar no município de Ijuí/RS as organizações com 100 (cem) ou mais empregados, entre estas, as que divulgam os dados referente à Pessoas com Deficiência (PcD), Mulheres, Negros e Pessoas com mais de 45 anos em seu BS e/ou RA. Ao final, configuram-se como critério de seleção da amostra as organizações que necessariamente já se defrontaram com o tema da diversidade em seu quadro de funcionários. Ressalta-se que para designar as cores ou raças, usou-se neste estudo a nomenclatura adotada pelo Instituto Brasileiro de Geografia e Estatística (IBGE): branca, preta, parda, amarela e indígena, considerando-se negra a população formada por pretos e pardos.

Abaixo o extrato da coleta de dados:

a) Amostra: Funcionários e dirigentes das 20 organizações do município de Ijuí/RS com mais de 100 empregados.

b) Período de campo: De 20 de maio de 2019 a 23 de outubro de 2019.

c) Coleta de dados: O questionário foi enviado por meio de mensagem eletrônica endereçada ao principal gestor e ao responsável pela área de recursos humanos ou de responsabilidade social. O Questionário apoia-se em dados do “Perfil Social, Racial e de Gênero das 500 Maiores Empresas do Brasil”, realizado pelo Instituto Ethos em parceria com o Banco Interamericano de Desenvolvimento (BID). Salienta-se que a parte qualitativa foi fundamental para completar a pesquisa quantitativa. Conforme autorização dos sujeitos, as entrevistas foram gravadas, fato que segundo Oliveira (2009) facilita o processo de transcrição e a aproximação com a própria narrativa dos entrevistados, na garantia da autenticidade das narrações.

Dessa forma, foram utilizadas duas possibilidades teóricas e práticas de análise do material qualitativo, como: análise de conteúdo $(\mathrm{AC})$ e análise do discurso $(\mathrm{AD})$. Nesta pesquisa, o estudo de caso apresenta-se como "estratégia de pesquisa" que compreende um recurso que abrange tudo, como parte lógica de planejamento, incorporando abordagens específicas à coleta de dados e à análise de dados" (Yin, 2001, p. 33).

\section{Resultados e Discussão}

Os resultados desta pesquisa são um misto de significados, experiências e interpretações. Este item visa conhecer o posicionamento dos sujeitos quanto à condição dos grupos presentes na estrutura da organização (pessoas com deficiência, negros, mulheres e indivíduos com mais de 45 anos). Esta parte da pesquisa dedica-se à análise dos resultados e a discussão dos dados com base no aporte teórico e nos autores que discutem o tema investigado.

\subsection{A "Terra das culturas diversificadas"}

Fundada em 19 de outubro de 1890, a Colônia de Ijuhy recebeu imigrantes de várias nacionalidades. O município de Ijuí é conhecido como “Terra das culturas diversificadas” por reunir variado grupo étnico: africanos, índios, portugueses, franceses, italianos, alemães, poloneses, austríacos, letos, holandeses, suecos, espanhóis, japoneses, russos, árabes, lituanos, ucranianos, entre outros. O município de Ijuí também é reconhecido como um dos 35 municípios gaúchos a incentivar pequenos negócios e implantar políticas públicas de desenvolvimento. Apresenta-se na $20^{\circ}$ posição dos municípios mais desenvolvidos do estado segundo o Índice de Desenvolvimento Socioeconômico (IDESE) total. A motivação inicial desse universo é devido à diversidade étnica, resultado da imigração de mais de quinze povos europeus. 


\subsection{Perfil corporativo}

A maior parcela do grupo participante da pesquisa, é do setor de serviços, com 54\%, seguido pelos setores de comércio, com $31 \%$ e indústria com $15 \%$. O setor de serviços representa $83 \%$ do total de funcionários das organizações que responderam ao questionário, na sequência o setor de comércio com $12 \%$ e indústria com a menor parcela, $5 \%$.

Do total de 20 organizações, todas convidadas a participar da pesquisa, um grupo de 13 devolveu o questionário com as partes preenchidas; destas, um grupo de 4 organizações solicitou informações adicionais via telefone e/ou e-mail. O grupo de 7 organizações que optaram em não participar do estudo, alegaram como causa a dificuldade de obtenção, na própria organização, dos dados requeridos. Destas, 5 organizações não preencheram a parte 3 do questionário, com as principais características de seus funcionários e dirigentes, alegando a falta de dados em seu sistema de gestão. Entre as dificuldades apontadas, para a não participação do estudo, aparecem também, a falta de informação e a falta de preparo da área de recursos humanos para tratar do tema. Duas organizações alegam desconforto em relação às questões do questionário.

Várias situações apresentadas evidenciaram que a maioria das organizações não possui programas de diversidade. Os dados apurados neste estudo demonstram que há ainda um quadro de desequilíbrio e assimetria que exige atenção e enfrentamento das organizações em relação às pessoas com deficiência, negros, mulheres e pessoas com mais de 45 anos de idade. Todos os questionários preenchidos foram checados por meio de contato telefônico e reuniões presenciais com os respondentes, quando necessário, a fim de esclarecer dúvidas e estimular a participação. Desta forma, o preenchimento foi completado com o apoio de entrevistas por telefone e/ou pessoalmente.

\subsection{Perfil dos sujeitos da pesquisa}

A classificação de "cor ou raça" está congruente com as reflexões teóricas de Nogueira (1979), e também com o critério adotado pelo IBGE de classificação racial, considerando a autoidentificação e considerando negros os indivíduos que se autoclassificam como preto. Vale ressaltar, em relação ao perfil demográfico, em pontos percentuais a região sul apresenta a menor proporção de negros no país $(4,8 \%)$, um leve crescimento de 1,2 pontos percentual. Os brancos continuam sendo maioria na região sul $(73,9 \%)$.

Na Tabela 1 é possível verificar a população residente por sexo, deficiência ${ }^{2}$, raça/cor e faixa etária para o Município de Ijuí, no Rio Grande do Sul/Brasil.

Tabela 1 - População por segmentos de estudo

\begin{tabular}{|c|c|c|c|c|c|c|}
\hline População Residente & Total & Homens & Mulheres & PcD & Negros & PCM45 \\
\hline Ijuí (RS) & 78.915 & 38.112 & 40.803 & 16.178 & 2.050 & 29.301 \\
\hline Rio Grande do Sul & 10.693 .929 & 5.205 .057 & 5.488 .872 & 2.548 .418 & 587.888 & 3.853 .587 \\
\hline Brasil & 190.755 .799 & 93.406 .990 & 97.348 .809 & 45.606 .048 & 14.351 .162 & 55.681 .382 \\
\hline
\end{tabular}

Fonte: IBGE (2010) - Censo Demográfico.

Optou-se por resguardar os sujeitos, omitindo seus nomes e os das organizações analisadas. Por questões éticas e para circular academicamente os sujeitos da pesquisa foram identificados por nomes de "flores". Os pseudônimos foram escolhidos em conjunto com a pesquisadora e pelas informantes.

\footnotetext{
${ }^{2}$ Nota: Existência ou não de pelo menos uma das deficiências investigadas.

Tabela 3428 - População residente, por existência ou não de pelo menos uma das deficiências investigadas e frequência à escola ou creche, segundo o sexo e os grupos de idade Amostra - Características Gerais da População. Tabela 2093 - População residente por cor ou raça, sexo, situação do domicílio e grupos de idade - Amostra - Características Gerais da População.
} 


\subsection{Políticas e ações afirmativas gerais}

Os postos de comando são menos acessíveis às pessoas com deficiência. É nesse nível da escala hierárquica que o grupo analisado por este estudo concentra a maior ausência de medidas para incentivar a presença dessas pessoas, com as seguintes proporções: $92 \%$ no quadro de estagiários, $77 \%$ no executivo, $77 \%$ na gerência, caindo para $69 \%$ na supervisão.

Das organizações pesquisadas, a maioria não possui medidas para incentivar e ampliar a presença de negros nos cargos. As maiores porcentagens estão nos postos de diretoria, gerência, supervisão e estagiários, ambos com 85\%, caindo para $77 \%$ no quadro funcional. Interrogadas quanto à adoção de alguma política de promoção da igualdade de oportunidades para negros e não negros, manifestaram-se afirmativamente só $15 \%$ do grupo. Nenhuma organização estabelece programas para a capacitação profissional visando melhorar a qualificação de negros para assumir postos não ocupados tradicionalmente por eles ou postos de maior nível hierárquico. Observa-se na tabela 2 as políticas e ações afirmativas para os segmentos analisados:

Tabela 2 - Políticas e ações afirmativas gerais.

\begin{tabular}{|c|c|c|c|c|c|}
\hline & Diretoria & Gerência & Supervisăo & Quadro Funcional & Estágiários \\
\hline & \multicolumn{5}{|c|}{ Politicas e ações afirmativas gerais - pessoas com deficiência \% } \\
\hline Politicas com metas e açôes planejadas & - & - & - & 15 & - \\
\hline Açőes pontuais & 23 & 23 & 31 & 31 & 8 \\
\hline \multirow[t]{2}{*}{ Näo possui medidas para incentivar e ampliar a presença de PCD } & 77 & 77 & 69 & 54 & 92 \\
\hline & \multicolumn{5}{|c|}{ Politicas e açōes afirmativas gerais - negros $\%$} \\
\hline Politicas com metas e açôes planejadas & - & - & - & 15 & 7 \\
\hline Ações pontuais & 15 & 15 & 15 & 8 & 8 \\
\hline \multirow[t]{2}{*}{ Nåo possui medidas para incentivar e ampliar a presença de negros } & 85 & 85 & 85 & 77 & 85 \\
\hline & \multicolumn{5}{|c|}{ Politicas e açôes afirmativas gerais - mulheres $\%$} \\
\hline Politicas com metas e açôes planejadas & 8 & 8 & 8 & 8 & 8 \\
\hline Açöes pontuais & 7 & 23 & 23 & 23 & 7 \\
\hline \multirow[t]{2}{*}{ Não possui medidas para incentivar e ampliar a presença de mulheres } & 85 & 69 & 69 & 69 & 85 \\
\hline & \multicolumn{5}{|c|}{ Politicas e açôes afirmativas gerais - pessoas com mais de 45 anos \% } \\
\hline Politicas com metas e açōes planejadas: & - & + & - & 8 & - \\
\hline Açöes pontuals & 23 & 31 & 31 & 46 & - \\
\hline Não possui medidas para incentivar e ampliar a presença de PCM45 & 77 & 69 & 69 & 46 & - \\
\hline
\end{tabular}

Fonte: Autores.

A maioria das organizações participantes desta pesquisa não tem ações afirmativas para incentivar a presença de mulheres em seus quadros. Essa negativa atinge a proporção de $85 \%$ nas respostas referentes ao grupo de estagiários, com o mesmo percentual o grupo de Diretoria, a partir do qual começa o afunilamento que reduz a participação feminina ao longo da escala hierárquica.

Vê-se também que uma parcela significativa das organizações não adota medidas para incentivar a presença, em seus quadros, de pessoas com mais de 45 anos. As maiores porcentagens estão nos postos de comando: diretoria (77\%) gerência e supervisão (69\%), caindo para $46 \%$ no quadro funcional. As demais corporações que afirmam adotar alguma medida de incentivo têm, em maior proporção, apenas ações pontuais, com o mesmo patamar dos níveis de gerência e supervisão (31\%). Apenas 15,38\% do grupo de organizações estabelece programas especiais para contratação de pessoas com mais de 45 anos, e 38,46\% disseram ter políticas e programas de capacitação profissional que visem melhorar a qualificação de pessoas com mais de 45 anos para assumir postos não ocupados tradicionalmente por elas ou postos de maior nível hierárquico. 


\subsection{Composição dos grupos minoritários}

Os resultados que se apresentam neste tópico dizem respeito às principais características de funcionários e dirigentes. Aqui, pretende-se definir seu perfil em sete níveis hierárquicos: conselheiros, o quadro executivo (presidentes, vice-presidentes e diretores), gerentes, supervisores, chefes ou coordenadores, o quadro funcional, estagiários e aprendizes.

\subsubsection{Composição dos grupos minoritários - Pessoas com deficiência}

O grupo analisado apresenta uma pequena parcela de pessoas com deficiência trabalhando em seu quadro geral. Os homens são maioria nesse contingente, com proporção de 53\%. As mulheres, com sua participação de $47 \%$, enfrentam um afunilamento também detectado nos capítulos de composição por sexo e por cor ou raça. Ou seja, quanto mais elevado é o nível hierárquico, maior é a exclusão das mulheres com deficiência. Outro ponto a observar, no quadro de aprendizes, estagiários, executivo e conselho, o grupo alcança $100 \%$ de pessoas sem deficiência. Na maioria dos cargos de comando, não há nem mulheres nem homens com deficiência, como é demonstrado na Tabela 3:

Tabela 3 - Composição: Pessoas com Deficiência (PCD) versus Pessoas sem Deficiência (PSD)\%.

\begin{tabular}{|c|c|c|c|c|c|c|c|c|c|c|c|c|c|c|c|c|}
\hline & \multicolumn{2}{|c|}{ Conselho } & \multicolumn{2}{|c|}{ Executivo } & \multicolumn{2}{|c|}{ Gerência } & \multicolumn{2}{|c|}{ Supervisão } & \multicolumn{2}{|c|}{ Estagiários } & \multicolumn{2}{|c|}{ Aprendizes } & \multicolumn{2}{|c|}{ Operacional } & \multicolumn{2}{|c|}{ Total Geral } \\
\hline \multirow{2}{*}{$\%$} & PCD & PSD & PCD & PSD & PCD & PSD & $\mathrm{PCD}$ & PSD & $\mathrm{PCD}$ & PSD & PCD & PSD & PCD & PSD & PCD & PSD \\
\hline & - & 100 & - & 100 & 2 & 98 & 3 & 97 & - & 100 & - & 100 & 3 & 97 & 2 & 98 \\
\hline
\end{tabular}

Fonte: Autores.

Dentre os trabalhadores empregados pelas organizações pesquisadas, a maioria é de pessoas com deficiência física. Esta tendência é observada desde a década de 60 , quando o pós-guerra consolidou a necessidade de inserção dos deficientes oriundos deste momento histórico. Outros estudos também apontam a deficiência física como a deficiência que tem prevalência em ocupação de vagas no mercado de trabalho (Lancillotti, 2003; Pereira \& Passerino, 2018). Observa-se na Tabela 4, a composição por tipo de deficiência.

Tabela 4 - Composição por tipos de deficiência \%.

\begin{tabular}{lc|c|c|c|c|c}
\hline Composição por tipos de deficiência \% & Física & Visual & Auditiva & Múltipla & \multicolumn{2}{|c}{ Intelectual } \\
\hline PcD em nível de gerência - Homens & 100 & - & - & - & - & \\
PcD em nível de gerência - Mulheres & 100 & - & - & - & - & \\
PcD em nível de supervisão - Homens & 50 & 25 & 25 & - & - & \\
PcD em nível de supervisão - Mulheres & 26 & 33 & 4 & 33 & 4 & \\
PcD em nível de Quadro Funcional - Homens & 51 & 26 & 19 & 1 & 3 & \\
PcD em nível de Quadro Funcional - Mulheres & 54 & 16 & 20 & 6 & 4 & \\
\cline { 2 - 7 } & &
\end{tabular}

Fonte: Autores.

Os resultados encontrados neste estudo juntam-se aos resultados obtidos por Suzano et al. (2014, p. 247), segundo os estudos, existe uma maior inserção de pessoas com deficiência física e auditiva no mercado de trabalho, em detrimento das pessoas com deficiência intelectual, como corroboram várias outras pesquisas (Bahia, Schommer \& Santos, 2008; Carneiro \& Ribeiro, 2009; Goulart \& Coimbra, 2008; Instituto Ethos, 2016). Para Suzano (2014, p. 247), "'mesmo aumentando o número de pessoas com deficiência no mercado formal de trabalho, ainda há uma desigualdade dessa inserção de acordo com o tipo de deficiência que a pessoa possui, o que pode estar associado ao estereótipo dessas deficiências. 


\subsubsection{Composição dos grupos minoritários - Negros}

É eloquente também a sub-representação dos negros nos níveis aqui estudados. Sua participação no quadro funcional é "desprezível" para ambos os sexos (Ethos, 2016). Mantendo-se num mesmo patamar no quadro de aprendizes, com $2 \%$ apenas. Considerando cargos de comando, somente há presença de negros no quadro de supervisão (homens). Um percentual bem pequeno considerando o contingente de funcionários.

Tabela 5 - Composição por cor ou raça \%.

\begin{tabular}{lc|c|c|c|c}
\hline & $\%$ Branca & Preta & Parda & Indígena & \\
Mulheres - Quadro & 92 & 2 & 6 & - & \\
Mulheres - Estagiários & 100 & - & - & - & \\
\cline { 2 - 7 } Mulheres - Aprendizes & 98 & 2 & & - & \\
\cline { 2 - 7 } Homens - Quadro & 89 & 2 & 9 & - & \\
Homens - Estagiários & 100 & - & - & - & \\
Homens - Aprendizes & 93 & 2 & 5 & - & \\
\hline
\end{tabular}

Fonte: Autores.

Também é expressiva a falta de negros entre os funcionários e dirigentes do grupo de organizações que se manifestaram, discorrendo os 7 níveis hierárquicos. Os brancos ocupam quase a totalidade dos níveis. Eles têm participação de 100\% no nível de conselho, executivo, gerência e no nível dos estagiários. E as mulheres negras têm condição ainda mais desfavorável, com participação $48 \%$ no quadro geral, em relação aos $60 \%$ dos homens negros. Quando questionados quanto à causa da escassez de negros em um ou mais níveis, parte dos gestores diz haver "à falta de interesse de negros por cargos na organização" e "à falta de qualificação profissional de negros para os cargos".

\subsubsection{Composição dos grupos minoritários - Mulheres}

As mulheres têm vantagem em relação aos homens no contingente de estagiários, quadro funcional e aprendizes, com participação de $67 \%, 52 \%$ e $51 \%$ respectivamente. Perdem espaço, no entanto, já a partir dos nos níveis de comando, estão ainda menos presentes, com porcentagens de $44 \%$ na supervisão, $27 \%$ no conselho de administração, 25\% na gerência e $16 \%$ no quadro executivo. A tabela 6, a seguir, demonstra a composição de mulheres e homens nos diferentes níveis hierárquicos.

Tabela 6 - Composição por sexo.

\begin{tabular}{r|c|c|c|c|c|c|c|c}
\hline & Conselho & Executivo & Gerência & Supervisão & Estagiários & Aprendizes & Quadro Funcional & \\
\hline Mulheres \% & 27 & 16 & 25 & 44 & 67 & 51 & 52 \\
\hline Homens \% & 73 & 84 & 75 & 56 & 33 & 49 & 48 \\
\hline \hline
\end{tabular}

Fonte: Autores.

Segundo levantamento da Estatística de Gênero e Indicadores Sociais das Mulheres no Brasil, 60,9\% dos cargos gerenciais eram ocupados por homens e 39,1\% pelas mulheres, em 2016. Em todas as faixas etárias havia uma maior proporção de homens ocupando os cargos gerenciais, o que se agrava nas faixas etárias mais elevadas (IBGE, 2018). 


\subsubsection{Composição dos grupos minoritários - Pessoas com mais de 45 anos}

O contingente acima de 45 anos tem presença de $67 \%$ no conselho administrativo, $79 \%$ no quadro executivo, $39 \%$ na gerência, $27 \%$ na supervisão e $30 \%$ no quadro funcional. Considerados esses cinco níveis, a proporção de funcionários da faixa acima de 45 anos é de $48 \%$. O estudo mostra que os funcionários da faixa etária de 46 a 56 ou mais, ocupam a maior parcela de dois níveis hierárquicos, mas com menor distribuição no quadro funcional.

Observa-se também, a respeito desse grupo, acentuada prevalência da faixa de 46 a 55 anos em relação à de 56 anos ou mais, com desnível de $20 \%$ para $10 \%$ no quadro funcional, $21 \%$ para $6 \%$ na supervisão, $31 \%$ para $8 \%$ na gerência e $54 \%$ para $25 \%$ no quadro executivo. É igualmente discreta a participação no conselho administrativo, de $40 \%$ para $27 \%$ considerados esses cinco níveis, conforme composição por faixa etária, demonstrado na Tabela 7 :

Tabela 7 - Composição por faixa etária.

\begin{tabular}{|c|c|c|c|c|c|c|c|}
\hline$\%$ & $\%$ Conselho & Executivo & Gerência & Supervisão & Estagiários & Aprendizes & Quadro \\
\hline De 16 a 24 anos & - & - & - & - & 77 & 93 & 11 \\
\hline De 25 a 35 anos & & 3 & 15 & 29 & 23 & 7 & 29 \\
\hline De 36 a 45 anos & 33 & 18 & 46 & 44 & - & - & 30 \\
\hline De 46 a 55 anos & 40 & 54 & 31 & 21 & - & - & 20 \\
\hline De 56 anos ou mais & 27 & 25 & 8 & 6 & - & - & 10 \\
\hline
\end{tabular}

Fonte: Autores.

Os resultados deste estudo dialogam com os estudos de Araújo e Antigo (2015), frise-se que o atributo pessoal idade é um fator que influencia significativamente nas probabilidades de trabalho. Indivíduos mais jovens (entre 15 e 29 anos) têm menor probabilidade de encontrar emprego ou se manterem empregados do que indivíduos com idade entre 30 e 49 anos. Pode-se concluir que aqueles com mais escolaridade têm maior probabilidade de se manterem empregados para todas as diferentes faixas etárias. Indagadas quanto a possíveis medidas de incentivo à presença, em seus quadros, de pessoas com mais de 45 anos, parcelas superiores a 60\% das organizações declaram não ter nenhuma, para 3 níveis considerados neste estudo.

\subsection{Práticas e falas: as incongruências entre o dito e o feito}

\subsubsection{Percepção dos gestores}

Os principais gestores consideram adequada a presença de pessoas com deficiência em cada um dos postos analisados: diretoria (77\%), gerência (54\%), supervisão (46\%) apresentando um elevado percentual no quadro funcional (62\%). Interessante observar, a não ocorrência de apontamento ao item "acima do que deveria".

Vê-se logo que a presença de negros nas organizações é adequada para os gestores no que diz respeito aos níveis de gerência, supervisão e quadro funcional. Ambos representados com 54\%. Os gerentes consideraram "abaixo do que deveria" no posto de diretoria. Mas, ainda não há resultados satisfatórios. Segundo os gestores a proporção de negros está abaixo do que deveria em função "da falta de interesse de negros por cargos na organização". A comparar pelas proporções relativas ao incentivo à presença de negros nas organizações, mais de $80 \%$ não possui medidas para incentivar e ampliar a presença de negros na organização. Observa-se na tabela 8 as principais percepções dos gestores: 
Tabela 8 - Percepção dos gestores.

\begin{tabular}{|c|c|c|c|c|}
\hline & Diretoria & Gerência & Supervisão & Quadro Funcional \\
\hline & \multicolumn{4}{|c|}{ Sobre a presença de pessoas com deficiência \% } \\
\hline Acima do que deveria & - & - & - & - \\
\hline Abaixo do que deveria & 23 & 46 & 54 & 38 \\
\hline \multirow[t]{2}{*}{ Adequada } & 77 & 54 & 46 & 62 \\
\hline & \multicolumn{4}{|c|}{ Sobre a presença de negros na organização \% } \\
\hline Acima do que deveria & - & - & - & - \\
\hline Abaixo do que deveria & 54 & 46 & 46 & 46 \\
\hline \multirow[t]{2}{*}{ Adequada } & $\begin{array}{r}46 \\
\end{array}$ & 54 & 54 & 54 \\
\hline & \multicolumn{4}{|c|}{ Sobre a presença mulheres nas organizações \% } \\
\hline Acima do que deveria & - & - & - & - \\
\hline Abaixo do que deveria & 15 & 31 & 23 & 23 \\
\hline \multirow[t]{2}{*}{ Adequada } & 85 & 69 & 77 & 77 \\
\hline & \multicolumn{4}{|c|}{ Sobre a presença de pessoas com mais de 45 anos \% } \\
\hline Acima do que deveria & - & - & - & - \\
\hline Abaixo do que deveria & - & - & 8 & 8 \\
\hline Adequada & 100 & 100 & 92 & 92 \\
\hline
\end{tabular}

Fonte: Autores.

São significativas as proporções dos principais gestores, ou de quem os representa nesta parte da pesquisa, que consideram adequada a presença de mulheres nos quatro níveis hierárquicos aqui considerados: quadro funcional (77\%), supervisão (77\%), gerência (69\%) e quadro executivo (85\%). Mais de $70 \%$ das organizações disseram não possuir medidas para incentivar a presença de mulheres nas organizações. Há também parcelas de gestores que veem a presença feminina "abaixo do que deveria" no quadro funcional (23\%), na supervisão (23\%), na gerência (31\%) e no quadro executivo (15\%).

As mulheres ocupam, no grupo de organizações que informaram as principais características de seu pessoal, $52 \%$ do quadro funcional, $44 \%$ da supervisão, $25 \%$ da gerência e $16 \%$ do quadro executivo. Indagados quanto à causa da restrita participação feminina em ao menos um dos níveis hierárquicos, parte dos gestores respondeu: à falta de qualificação profissional de mulheres para os cargos e à falta de interesse de mulheres por cargos na organização.

Observa-se, de início, a elevada proporção de gestores que percebem como adequada a presença de pessoas com mais de 45 anos nos quatro níveis hierárquicos: diretoria e gerência, ambos correspondem a 100\%, supervisão e quadro funcional, são mais de $90 \%$. É, no entanto, uma proporção que sugere, de acordo com a opinião desses dirigentes, ser mais adequado pessoas com idade acima de 45 anos estarem no topo da escala hierárquica. Verifica-se que pessoas com mais de 45 anos tem sido tendência nas posições de comando nas organizações ijuienses, principalmente em níveis de conselho, executivo e gerência. Nas organizações estudadas a imagem do dirigente, ou de profissionais em cargos de chefia ainda mais altos, está vinculada a "cabelos brancos", muitos anos de experiência e idade também. Ou seja, ainda permanece a figura do profissional "velho de carteira". Compreende-se que a necessidade de ter mais de 45 anos, pelo menos, para atingir altos cargos ainda é uma inclinação entre as organizações aqui estudadas. A percepção dos gestores aparentemente reflete no modo como as corporações encaram essa questão.

Outro dado relevante, diz respeito aos mais jovens de 25 a 45 anos que já representam $73 \%$ na supervisão. Nessa perspectiva, pode-se observar que um dos desafios em assumir um cargo de chefia tão jovem é lidar com colaboradores tidos "mais velhos e conservadores". Acresça-se a isso ao registro de que se a proporção de pessoas com mais de 45 anos de idade está abaixo do que deveria em um desses níveis, é atribuída apenas "à falta de conhecimento ou experiência da organização para lidar com o assunto" 


\subsubsection{Pessoas com deficiência nas organizações}

Alguns gestores entrevistados reconhecem que as organizações têm procurado a inserção de pessoas com diferentes perfis, no entanto, também reconhecem que a validade dessa ação é ameaçada quando os indivíduos não depositam crédito na diversidade e quando há falta de oportunidades de ascensão e/ou de reconhecimento. Quanto a isso, observa-se nas falas apresentadas no Quadro 1:

Quadro 1 - Pessoas com deficiência: Incongruências entre o dito e o feito.

\begin{tabular}{|c|c|c|c|c|c|}
\hline Extratos das falas & Nomes & Setor & $\begin{array}{c}\text { Raça ou } \\
\text { Cor }\end{array}$ & Sexo & Tipo \\
\hline $\begin{array}{l}\text { "As organizações precisam parar com a ideia de } \\
\text { empacotar as pessoas. Como se todos fossem } \\
\text { iguais. Isso tira o aspecto de criatividade e } \\
\text { naturalidade do ambiente corporativo [...]". }\end{array}$ & Sálvia & Gestão & Branca & Masculino & - \\
\hline $\begin{array}{l}\text { "[...] Eu tenho deficiência motora, mas os } \\
\text { colegas acham que eu tenho deficiência } \\
\text { cognitiva... Uma deficiência não quer dizer que a } \\
\text { pessoa seja um mal profissional. Tem deficientes } \\
\text { que são melhores que outros profissionais[...]." }\end{array}$ & Primula & Operacional & Branca & Masculino & $\begin{array}{l}\text { Deficiência } \\
\text { Física }\end{array}$ \\
\hline $\begin{array}{l}\text { "Infelizmente as organizações contratam pessoas } \\
\text { com deficiência para cumprir a lei de cotas. Não } \\
\text { acreditam no potencial das PcDs e não } \\
\text { conseguem integrar totalmente." }\end{array}$ & Gardênia & Operacional & Branca & Feminino & - \\
\hline $\begin{array}{l}\text { "Quando eu ingressei no mercado de trabalho eu } \\
\text { percebi que as vagas disponíveis para PcD eram } \\
\text { inferiores a formação da pessoa dita como } \\
\text { "diferente" .. As vagas são destinadas para } \\
\text { áreas que eu não tenho formação e se eu } \\
\text { concorrer na ampla concorrência não serei } \\
\text { chamada." }\end{array}$ & Torênia & Administrativo & Branca & Feminino & $\begin{array}{l}\text { Deficiência } \\
\text { Física }\end{array}$ \\
\hline $\begin{array}{l}\text { "A falta de acessibilidade em alguns pontos aqui } \\
\text { na empresa prejudica o meu acesso em algumas } \\
\text { áreas. Às vezes eu preciso fazer muita força para } \\
\text { descer em alguns locais [...]". }\end{array}$ & Primula & Operacional & Branca & Masculino & $\begin{array}{l}\text { Deficiência } \\
\text { Física }\end{array}$ \\
\hline $\begin{array}{l}\text { "Ele[colega] falou que não ajudaria a PcD. Eu } \\
\text { passei para a supervisora este caso. Acho que ela } \\
\text { não se importou com isso... Uma pessoa com } \\
\text { deficiência não escolhe estar nessa condição." }\end{array}$ & Coreópsis & Operacional & Branca & Feminino & - \\
\hline $\begin{array}{l}\text { "Aqui na empresa piadinhas é 'normal'. Também } \\
\text { acho que isso não vai acabar. A gente sofre na } \\
\text { pele, mas a gente não tem o que fazer". }\end{array}$ & Àster & Operacional & Branca & Masculino & $\begin{array}{l}\text { Deficiência } \\
\text { Física }\end{array}$ \\
\hline $\begin{array}{l}\text { "A empresa contrata para cumprir a lei de cotas. } \\
\text { Acho que as empresas em geral têm dificuldade } \\
\text { de lidar com PcD". }\end{array}$ & Alamanda & Administrativo & Branca & Feminino & $\begin{array}{l}\text { Deficiência } \\
\text { Visual }\end{array}$ \\
\hline $\begin{array}{l}\text { [...] "As empresas contratam PcD porque são } \\
\text { obrigadas." }\end{array}$ & Vinca & Operacional & Preta & Masculino & $\begin{array}{c}\text { Deficiência } \\
\text { Auditiva }\end{array}$ \\
\hline $\begin{array}{l}\text { "As empresas contratam pessoas com deficiência } \\
\text { apenas para cumprir a lei, por conta dos } \\
\text { impostos. Também acho que os gestores possuem } \\
\text { resistência em entrevistar pessoas com } \\
\text { deficiência". }\end{array}$ & Peônia & Administrativo & Parda & Feminino & - \\
\hline "Infelizmente se não existisse a lei de cotas não & Clúsia & Gestão & Branca & Masculino & - \\
\hline
\end{tabular}




\begin{tabular}{|c|c|c|c|c|c|}
\hline $\begin{array}{l}\text { teria tanta contratação de PcD. As empresas } \\
\text { fazem publicidade com isso. Não basta cumprir a } \\
\text { lei, acho que a inclusão requer mudanças na } \\
\text { forma de pensar..." }\end{array}$ & & & & & \\
\hline $\begin{array}{l}\text { "A empresa contrata por conta da legislação, } \\
\text { [...] os gestores não têm conhecimento para } \\
\text { contratar PcD. "Ficam sem jeito", não sabem o } \\
\text { que perguntar." }\end{array}$ & Dália & Administrativo & Branca & Feminino & $\begin{array}{l}\text { Deficiência } \\
\text { Física }\end{array}$ \\
\hline $\begin{array}{l}\text { "Os gestores estavam preocupados em como } \\
\text { lidar com as pessoas com deficiência. Mas } \\
\text { durante o processo de acolhida perceberam que } \\
\text { muitas vezes o problema estava muito mais na } \\
\text { cabeça de quem não possui deficiência" }\end{array}$ & Sálvia & Gestão & Branca & Masculino & - \\
\hline $\begin{array}{l}\text { "As pessoas sem deficiência têm um pouco de } \\
\text { medo. Eu acho que uma das principais barreiras } \\
\text { para a inclusão das pessoas com deficiência no } \\
\text { mercado formal de trabalho é a aceitação e a } \\
\text { acessibilidade. A Pcd quer ser útil, conseguir se } \\
\text { formar com dignidade... A verdadeira inclusão } \\
\text { ocorre quando recebemos as mesmas } \\
\text { oportunidades de qualificação no mercado de } \\
\text { trabalho." }\end{array}$ & Torênia & Administrativo & Branca & Feminino & $\begin{array}{l}\text { Deficiência } \\
\text { Física }\end{array}$ \\
\hline
\end{tabular}

Fonte: Autores.

Na declaração de "Sálvia" é possível refletir sobre a aceitação das diferenças individuais e na valorização do indivíduo. Aceitar a diversidade está muito além da fala. A legítima inclusão deve estar no processo e não apenas no discurso das organizações. É um processo contínuo de cooperação e conhecimento. Para Ross (2019, p.376) “a deficiência não é uma determinação biológica. A deficiência adquire valorização positiva ou negativa de acordo com as atribuições sociais e políticas".

Conforme algumas manifestações de PcDs e não-minorias, o modo como os recrutadores e gestores realizam o processo de seleção pode inibir ou potencializar "o desabrochar" das pessoas com deficiência. No entanto, os recrutadores precisam estar preparados para avaliar candidatos com deficiência, levando em consideração suas habilidades, possibilidades e também a deficiência. O processo deve permitir que o candidato possa participar sem ser discriminado e que não encontre nenhuma barreira para realizar qualquer uma das etapas, conforme evidenciados no quadro 1 deste estudo.

A partir da análise do depoimento de "Torênia", percebe-se que algumas organizações na busca de cumprir a lei de cotas para PcDs equivocam-se no processo de seleção e oferecem oportunidades inferiores ao perfil desses profissionais. De acordo com Le Breton (2003): [...] "a visão negativa construída em torno das pessoas que possuem algum tipo de deficiência, proporciona uma análise contrária da essência do ser humano". Por isso, os deficientes bem preparados são nivelados por baixo. Os depoimentos abaixo ilustram o cotidiano de pessoas com deficiência desbravando territórios pouco explorados por este segmento. Percebe-se claramente as contradições entre os discursos e as práticas adotadas pelas minorias e não minorias.

\section{Depoimento - minoria:}

"A empresa não disponibiliza intérprete de libras para reuniões e eventos. Eu me comunico apenas por libras, é difícil me adaptar ao ambiente de trabalho, em raras oportunidades havia intérprete para me ajudar. $O$ surdo apenas usa outra língua, ele necessita de um intérprete”... (Alfazema, deficiência auditiva, 2019 - Entrevista).

"Não me sentia útil na função anterior. Eu sei que tenho potencial para muito mais. Gosto de trabalhar aqui. No início não foi fácil, eu tentava fazer leitura labial e tinha de contar com a ajuda de colegas para entender sobre o trabalho" (Gailárdia, deficiência auditiva, 2019- Entrevista). 


\section{Depoimento - não minoria:}

"Este ano recebemos em nosso setor uma mulher com deficiência auditiva. Acho que temos de enfrentar essas dificuldades e fazer com que ela se sinta inserida em nosso ambiente. A princípio, ela está gostando do trabalho. Temos dificuldade de comunicação, mas eu acho que PcD são bem cientes neste sentido. Escrevemos para a gente se comunicar. Procuramos receber todos da melhor forma possível”(Orquídea, gestora, 2019 - Entrevista).

"Nós temos colegas surdos e todos os funcionários fizeram o curso de libras para integrá-los no nosso ambiente de trabalho. Temos em torno de 60 pessoas capacitadas. Aprendemos muito com eles, inclusive o "Gailárdia", deficiente auditivo é quem ministra as aulas. Estamos engajados neste processo de inclusão. Além disso, estamos adaptando os espaços físicos” (Margarida, ECM45, gestora, 2019 - Entrevista).

"O processo seletivo para contratação de PcDs ocorre entre as PcDs. É um processo separado. Eles não disputam com o conjunto. A gente "adapta" a deficiência com a vaga que tem. Não restringimos ninguém pelo fato de ter deficiência. Apenas olhamos se para determinada atividade a deficiência física é limitante ou não. Estamos realizando um novo trabalho de banco de currículos. É um desafio encontrar a pessoa certa para o cargo certo" (Sálvia, gestor, 2019 - Entrevista).

A entrevistada "Violeta" faz parte do grupo das minorias deste estudo. Ela é mulher, negra, 46 anos de idade e com deficiência física. Os relatos de Violeta levam-nos a uma reflexão sobre a relação que há entre gênero, deficiência, raça e faixa etária. Ela diz: "Algumas empresas estipulam o tipo de deficiência e que a pessoa não seja tão limitante. Ora, o que é mais limitante? Ter deficiência? Ter cabelo "ruim”? Ou ainda ser mulher? Qual a ordem das limitações?” ... (Violeta, deficiência física, negra, com 46 anos, 2019 - Entrevista).

Fica evidente a partir dos depoimentos que a admissão é feita sem planejamento pelas organizações, apenas com vistas a cumprir a lei vigente. Não apenas os dirigentes pensam dessa forma. Outros sujeitos da pesquisa deixam claro que a legislação é a principal razão para a contratação de pessoas com deficiência nas organizações.

\subsubsection{Negros nas organizações}

O gestor "Sálvia" esclarece que os dados a respeito de raça/cor são autodeclaratório. É provável que haja mais negros no quadro de pessoal. Enfatiza também que o preenchimento das informações é realizado pelo próprio empregado sem a interferência do empregador. Após são lançadas no sistema de gestão da organização. Por mais que a pessoa tenha uma aparência de branco, a pessoa pode se declarar como negro.

Por outro lado, Munanga (2004) ressalta que há pessoas negras que introjetam o ideal de branqueamento e não se consideram como negras. Assim, a questão da identidade do negro é um processo doloroso. Os conceitos de negro e de branco têm um fundamento etno-semântico, político e ideológico, mas não um conteúdo biológico. Nota-se que o sujeito "Congéia" falou à pesquisadora que nunca sofreu discriminação racial porque não é negro. Ao mesmo tempo, que as indicações que deram sobre este profissional, identificam-no como negro. Em sua fala fica evidente a autoidentificação como "não-negro". 
Quadro 2 - Negros: Incongruências entre o dito e o feito.

\begin{tabular}{|c|c|c|c|c|}
\hline Extratos das falas & Nomes & Setor & Raça ou Cor & Sexo \\
\hline $\begin{array}{l}\text { "Não temos uma política mais formal para os negros [...]. Poucas } \\
\text { pessoas negras participam dos nossos processos seletivos. A } \\
\text { quantidade de pessoas negras na nossa região ainda é pequena. Ijuí } \\
\text { é uma região 'branca'[...]". Para mim, algumas pessoas aqui na } \\
\text { organização são negras (visualmente) mas no sistema o empregado } \\
\text { se define como branco [...]. Não consigo entender o porquê disso? } \\
\text { (Pausa). Às vezes eu me acho mais negro no que o cara que é preto. } \\
\text { Por exemplo: a mãe dele é essa aqui (olhamos a imagem no } \\
\text { sistema), ela é preta, mas se define como branca. Ou seja, são } \\
\text { pessoas negras, mas não se definem como negras. Por isso não } \\
\text { encontramos negros por aqui. Identificamos várias situações como } \\
\text { essas (pessoas negras que se definem como brancas). Nós não } \\
\text { discutimos sobre isso com o empregado. O cara preenche a fichinha } \\
\text { dele e não tem problema. Provavelmente temos mais negros do que } \\
\text { informamos no questionário" }\end{array}$ & Sálvia & Gestão & Branca & Masculino \\
\hline $\begin{array}{l}\text { "A gente percebe o racismo nas oportunidades que não são dadas, } \\
\text { nos cargos, no tratamento desigual, e na desconfiança das pessoas... } \\
\text { Causa estranheza vê um negro trabalhando em um escritório aqui } \\
\text { em Ijuí." }\end{array}$ & Cinerária & Operacional & Preta & Masculino \\
\hline $\begin{array}{l}\text { "Minha tata é negra, trabalha conosco, minhas filhas são } \\
\text { apaixonadas por ela. Trabalha conosco há muito tempo...A gente } \\
\text { procura incluir todas as pessoas ..." }\end{array}$ & Orquídea & Gestão & Branca & Feminino \\
\hline $\begin{array}{l}\text { "Hoje em dia, tudo o que se fala é Bullying, é humilhação, é } \\
\text { racismo. Se me chamar de alemão eu tenho que ficar quieto. Se eu } \\
\text { chamar uma pessoa que é negra de negro, eu sou processado..." }\end{array}$ & Miosótis & Gestão & Branca & Masculino \\
\hline $\begin{array}{l}\text { "[...] Os clientes se referiam a mim assim, óh: eu falei com aquela } \\
\text { negrinha. "A negrinha" bonitinha, a do cabelo...diziam alguns } \\
\text { clientes." }\end{array}$ & Azaleia & Administrativo & Preta & Feminino \\
\hline $\begin{array}{l}\text { "A gente brinca lá na minha casa e temos mania de dizer: "aquela } \\
\text { negrada"... }\end{array}$ & Tulipa & Gestão & Branca & Feminino \\
\hline $\begin{array}{l}\text { "O preconceito ainda segue nas empresas em forma de apelidos e de } \\
\text { brincadeira pejorativas. Um exemplo: eu não sou moreno, não sou } \\
\text { chocolate, nem café... Eu sou preto. Sou "Negão". Eu tenho orgulho } \\
\text { de ser negro e ser "negão". }\end{array}$ & Cinerária & Operacional & Preta & Masculino \\
\hline $\begin{array}{l}\text { "Eu já fui chamada de "macaca" por conta do meu cabelo crespo. } \\
\text { Isso dói. Se eu reclamar eu fico sem emprego. A culpada ainda sou } \\
\text { eu." }\end{array}$ & Alpínia & Administrativo & Preta & Feminino \\
\hline $\begin{array}{l}\text { "Meu cabelo foi elogiado pela colega, daí o meu chefe disse que era } \\
\text { só ela deixar uns três dias sem lavar que ficava daquele jeito... Ele } \\
\text { falava que eu tinha "cabelo ruim". }\end{array}$ & Violeta & Administrativo & Preta & Feminino \\
\hline $\begin{array}{l}\text { Eu sou mais escuro porque trabalhei bastante no sol. Meus filhos } \\
\text { também são mais moreninhos... }\end{array}$ & Congeia & Operacional & Preta & Masculino \\
\hline
\end{tabular}

Fonte: Autores.

Entre os relatos apresentados no Quadro 2, a fala da entrevistada 'Azaleia" expressa bem o sofrimento de muitas pessoas negras; sentem-se deslocadas, submetidas a condições sociais de inferioridade e desvalorizam suas características físicas e suas capacidades intelectuais. Tais sentimentos decorrem de situações vividas diariamente nas relações interpessoais. Rompe-se com as verdades socialmente construídas de que para ser belo, competente, é preciso ser branco e ser magro. A entrevistada "Alpínia" foi chamada de "macaca". Essa associação é feita, fundamentalmente, por causa da cor, ou seja, ao chamar um negro de macaco, o indivíduo faz uma associação entre um humano e um não-humano.

Embora não sendo explícita no sentido verbal ou de atitude conscientemente racista, os danos causados por tais acontecimentos, que se repetem durante toda a vida dos negros em uma sociedade racista, ainda não foram devidamente dimensionados por psicólogos, sociólogos, e outros estudiosos do comportamento humano, porém, não é difícil de perceber as 
marcas deixadas por tais lembranças (Nogueira, 1979). Por outro lado, fica expresso nas falas dos sujeitos que a população negra vem se tornando visível, mesmo que, aos "trancos e barrancos".

Observa-se a questão levantada pelo pseudônimo "Miosótis", no quadro 2: "Hoje em dia, tudo o que se fala é Bullying, é humilhação, é racismo. Se me chamar de alemão eu tenho que ficar quieto. Se eu chamar uma pessoa que é negra de negro, eu sou processado... " Ressalta-se que a escravidão do Brasil foi um processo de longa duração. Se hoje em dia, "tudo é racismo", durante o período da escravidão, "nada era racismo". Portanto, falar sobre o racismo será cada vez mais necessário. Cabe a ressalva que o movimento negro foi responsável por muitas conquistas deste segmento. Portanto, "os que pensam que a situação do negro no Brasil é apenas uma questão econômica e não racista, não fazem um esforço para entender como as práticas racistas independem ao negro o acesso na participação econômica (Munanga, 1996 p. 8).

O sujeito "Cinerária" acrescenta:

"O negro enfrenta dificuldades para ser contratado nas organizações pois a questão estética ainda aparece bastante porque remete a história de cultura e escravidão e invisibilidade [...]. Os detentores de poder desde o começo da nossa história até agora sempre foram os brancos, então eles galgaram os grandes cargos e isso segue de geração em geração [...], o filho do médico branco será médico. O seu filho também será branco e médico. Isso vai seguir assim. A gente sabe que o próprio paciente prefere médicos brancos. Algumas pessoas ficam espantadas e desconfiadas em ver um médico negro no posto de saúde [...]. Os brancos começaram num patamar alto e vão continuar num patamar alto! Sempre será a maior massa" (Cinerária, EN, 2019 - Entrevista).

Dentre as bandeiras de luta, destaca-se o direito à educação. "Para nós negros é bem mais difícil a ascensão profissional, mas o estudo é a nossa única esperança”, enfatiza Cinerária, sujeito participante dessa pesquisa. Para Gonçalves, (2000, p. 337) a educação esteve sempre presente na agenda dos movimentos, embora concebida com significados diferentes: "ora vista como estratégia capaz de equiparar os negros aos brancos, dando-lhes oportunidades iguais no mercado de trabalho; ora como veículo de ascensão social e por conseguinte de integração; ora como instrumento de conscientização por meio da qual os negros aprenderiam a história de seus ancestrais, os valores e a cultura de seu povo, podendo a partir deles reivindicar direitos sociais e políticos, direito à diferença e respeito humano" .

\subsubsection{Mulheres nas organizações}

A luta da mulher pela sua emancipação e reconhecimento em relação ao sistema social patriarcal é clássica. Dentro de um contexto de uma sociedade capitalista, essa emancipação social idealizada pelo sexo feminino passa, impreterivelmente, pela independência no campo econômico. Os relatos dos sujeitos apresentados a seguir, no quadro 3, deixam claro que há ainda muito a se pensar, elaborar e debater sobre desigualdade de gênero no mercado de trabalho.

Historicamente, construiu-se a ideia de que o trabalho feminino constituiria simplesmente um complemento ao trabalho masculino e que, portanto, teria menos valor. Com isto, criava-se um padrão de trabalhos mal remunerados, geralmente vinculados às funções ditas femininas e que acabam por conferir salários inferiores às mulheres. Destacam-se aqui os depoimentos de "Rosa" e "Coreópolis" (Quadro 3). Além de diversas barreiras, as mulheres precisam superar problemas como obstáculos salariais, ganham menos que os homens, executando a mesma função. Não bastasse isso, o machismo faz com que elas sejam discriminadas no acesso aos melhores cargos. Estudo realizado por Barros (2008) corrobora com a proposição de "Coreópsis", afirmando que se perpetuam como fortes estereótipos negativos ao trabalho feminino a premissa social de que as mulheres possuem menor força física e disposição para enfrentar o perigo

$\mathrm{O}$ relato de Aurora complementa a análise quantitativa deste constructo. Ao examinar o número de homens e mulheres em cargos superiores nas organizações, nota-se um afunilamento hierárquico que exclui a mulher dos cargos de comando. Já no nível mais básico da administração, pode-se observar uma certa igualdade de gênero. Contudo, quando subimos na pirâmide, a dimensão do desafio que enfrentamos fica clara. 
Quadro 3 - Mulheres: Incongruências entre o dito e o feito.

\begin{tabular}{|c|c|c|c|c|}
\hline Extratos das falas & Nomes & Setor & Raça ou Cor & Sexo \\
\hline $\begin{array}{l}\text { "Os homens acham que não temos capacidade de fazer melhor } \\
\text { que eles. [...]. Eles já ingressam ganhando mais que as } \\
\text { mulheres... Nós fazemos o mesmo trabalho, muitas vezes, até } \\
\text { melhor que um homem. Mas nunca levamos os créditos. As } \\
\text { façanhas são sempre deles. Ainda mais na área de vigilância." }\end{array}$ & Rosa & Operacional & Branca & Feminino \\
\hline $\begin{array}{l}\text { "Somos desacreditadas nessa área [vigilância] porque somos } \\
\text { mulheres. Pensam que os homens possuem mais capacidade } \\
\text { que as mulheres. São os mais fortes!" }\end{array}$ & Coreópsis & Operacional & Branca & Feminino \\
\hline $\begin{array}{l}\text { "O homem tem mais poder e mais autoridade que a mulher. } \\
\text { Quando o homem fala parece que, pelo tom de voz, tem mais } \\
\text { autonomia e mais firmeza. É difícil conversar com os homens } \\
\text { nas obras. Somos interrompidas o tempo todo. Querem nos } \\
\text { ensinar. Para eles, lugar de mulher não é nas obras [...]." }\end{array}$ & Alpínia & Administrativo & Preta & Feminino \\
\hline 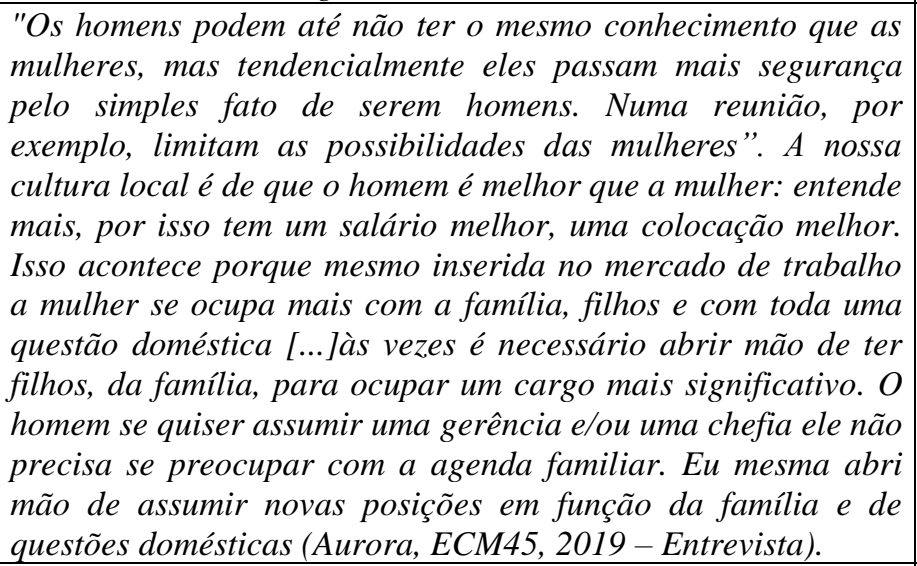 & Aurora & Gestão & Branca & Feminino \\
\hline $\begin{array}{l}\text { "Minha chefe precisa muitas vezes falar grosso para ser } \\
\text { respeitada pelos homens. Ela chefia como homem!" }\end{array}$ & Azaleia & Administrativo & Preta & Feminino \\
\hline $\begin{array}{l}\text { "Para mulheres ainda é mais difícil subir na carreira do que } \\
\text { para homens, talvez por preconceito mesmo... Falas do tipo: } \\
\text { não vai dar conta porque tem filhos para cuidar e outras } \\
\text { preocupaçães. Muitas mulheres optam por não ter filhos } \\
\text { porque acham que vai dificultar a carreira profissional. É triste } \\
\text { ter que escolher entre ser mãe e crescer profissionalmente" }\end{array}$ & Babosa & Administrativo & Branca & Feminino \\
\hline $\begin{array}{l}\text { "Quando a mulher se torna mãe é bem mais difícil, as } \\
\text { obrigações aumentam, são muitas responsabilidades. Eles } \\
\text { acham que as mulheres grávidas são incompetentes. Já vi } \\
\text { mulheres perdendo cargos de chefia por estar num período de } \\
\text { ser mãe [...]" }\end{array}$ & Jasmim & Administrativo & Branca & Feminino \\
\hline $\begin{array}{l}\text { "[...] eu já tive que procurar meu chefe por questão de assédio } \\
\text { de "senhores". É horrivel! Isso vem de pessoas que se espera } \\
\text { uma postura diferente, que são gestores" }\end{array}$ & Dália & Administrativo & Branca & Feminino \\
\hline $\begin{array}{l}\text { "Ijuí é um município do interior e por isso tem uma cultura } \\
\text { mais machista. Comportamentos machistas como ver uma } \\
\text { mulher passar e ficar comentando. Eu escuto comentários } \\
\text { machistas do meu chefe constantemente. As mulheres não são } \\
\text { respeitadas como profissionais. Se reclamamos acham que é } \\
\text { frescura e que estamos exagerando". }\end{array}$ & Astilbe & Administrativo & Branca & Feminino \\
\hline
\end{tabular}

Fonte: Autores.

O sujeito que recebeu o pseudônimo de "Clúsia" é gestor, tem 31 anos de idade e é docente. Ele faz a seguinte revelação: “Como ser humano eu contrataria uma mulher gestante, mas como gestor, não!’. Interessante observar que não somente este sujeito, mas alguns entrevistados do sexo masculino disseram que era melhor as mulheres não terem filhos se quisessem progredir em suas carreiras. Ao encontro disso, algumas mulheres também compartilham do mesmo pensamento. A 
entrevistada "Gardênia" expõe seu sofrimento ao retornar ao trabalho: [...] "acho que as mulheres sentem medo de retornar ao trabalho após o período de licença maternidade e serem demitidas e constrangidas em meio aos pares [...]". As empresas preferem os homens porque eles não engravidam...

Pontos relatados pelas entrevistadas expostos no quadro 3, dialogam com Saraceno (1995), isto é, quando as mulheres se impõem são vistas como masculinizadas ou desequilibradas. Esses julgamentos atrapalham a vida profissional. Entretanto, desqualificá-las significa negar qualquer valor social às necessidades de assistência e solidariedade, o que reforçaria ainda mais a divisão sexual do trabalho, na medida em que vincularia a ação da mulher a algo sem valor, sem mérito, invisível, sem reconhecimento. E esta concepção interessaria à lógica do capitalismo, pois o Estado isenta-se de suas responsabilidades, transferindo-as para a sociedade, através dos indivíduos, famílias e redes de voluntariado.

\subsubsection{Pessoas com mais de 45 anos nas organizações}

Com base nas respostas colhidas na fase quantitativa percebe-se que quando as organizações precisam de talentos com potencial é por meio de programas de estágios, jovem aprendiz e ainda trainees que procuram jovens. Mas, se o cargo requer disseminação de valores e competência, ela contrata pessoas mais experientes. A sociedade ainda precisa de um melhor preparo para administrar essa situação.

A partir desses elementos citados pelos sujeitos vêm à tona: Qual é o lugar de fala dos "mais velhos"? Ao revisar os resultados quantitativos deste estudo, observa-se o diálogo entre a pesquisa quantitativa e a qualitativa no que diz respeito aos cinco níveis hierárquicos: conselho administrativo, quadro executivo, gerência, supervisão e quadro funcional. O estudo mostra que os funcionários da faixa etária de 46 a 56 ou mais, ocupam a maior parcela de dois níveis de comando, mas com menor distribuição no quadro funcional.

Acentua-se nas falas a falta de paciência das pessoas mais jovens e o equilíbrio das pessoas mais velhas. Os ditos "mais maduros" são mais experientes, muitas vezes atuam como conselheiros e companheiros dos mais jovens. Por outro lado, ditos "mais malucos" transmitem mais energia jovial aos mais experientes. A maioria dos gestores ouvidos neste estudo sinaliza que o convívio com os mais jovens é fundamental, oxigena as relações e atualiza as vivências. Algumas organizações supervalorizam a juventude, a autonomia e a beleza. $\mathrm{O}$ velho passa a ser menosprezado e desvalorizado.

Para Barroso e Santos (2018) o processo de envelhecimento não é marcado só por perdas, mas também por ganhos, mas o que denunciará a velhice é o olhar da sociedade sobre o sujeito, e não o olhar do ego sobre si mesmo. De forma que a percepção de estar envelhecendo se dará no movimento em que o ego tentará se aproximar do que ele pensa de si, e daquilo que a cultura diz que ele é. Observa-se o Quadro 4: 
Quadro 4 - Pessoas com mais de 45 anos: Incongruências entre o dito e o feito.

\begin{tabular}{|c|c|c|c|c|c|}
\hline Extratos das falas & Nomes & Setor & Raça ou Cor & Sexo & Grupo \\
\hline $\begin{array}{l}\text { "As empresas relutam em admitir trabalhadores que } \\
\text { se encontram na faixa etária acima de } 45 \text { anos." }\end{array}$ & Miosótis & Gestão & Branca & Masculino & PCM45 \\
\hline $\begin{array}{l}\text { "O que eu percebo é o preconceito com pessoas com } \\
\text { mais idade, acham que estas pessoas cansam mais } \\
\text { [...]. Minha colega tinha setenta anos e era cheia de } \\
\text { energia." }\end{array}$ & Margarida & Gestão & Branca & Feminino & PCM45 \\
\hline $\begin{array}{l}\text { "As pessoas com mais de } 45 \text { anos têm mais } \\
\text { dificuldade com a tecnologia e isso pode dificultar o } \\
\text { ingresso em determinados setores. A pessoa mais } \\
\text { velha só quer ser útil e respeitada [...] Só quer ter } \\
\text { um trabalho decente e viver com saúde e } \\
\text { dignidade." }\end{array}$ & Íris & Gestão & Parda & Masculino & - \\
\hline $\begin{array}{l}\text { "A diversidade etária no ambiente de trabalho traz } \\
\text { muitos benefícios. Equipes iguais não inovam." }\end{array}$ & Astilbe & Administrativo & Branca & Feminino & - \\
\hline $\begin{array}{l}\text { "As empresas ganham quando elas têm um conjunto } \\
\text { de diversidade. Uma coisa é a padronização de } \\
\text { tarefas, outra, é pensar na organização, pensar no } \\
\text { jeito de fazer, como fazer... E isso é da parte criativa } \\
\text { do ser humano." }\end{array}$ & Sálvia & Gestão & Branca & Masculino & PCM45 \\
\hline $\begin{array}{l}\text { "Tem uma questão de postura profissional: os } \\
\text { jovens vão aprendendo com os mais velhos e os mais } \\
\text { velhos aprendendo com os mais jovens. O mais } \\
\text { jovem tem muita vontade de crescer. Isso é bom, } \\
\text { mas o jovem precisa compreender que existem } \\
\text { etapas." }\end{array}$ & Aurora & Gestão & Branca & Feminino & PCM45 \\
\hline $\begin{array}{l}\text { "A empresa quer pessoas mais jovens, que tenham } \\
\text { uma força bruta maior. As pessoas mais velhas vão } \\
\text { perdendo a força e a agilidade. Os mais jovens } \\
\text { querem "mostrar serviço." }\end{array}$ & Congeia & Operacional & Preta & Masculino & PCM45 \\
\hline $\begin{array}{l}\text { A empresa contrata pessoas mais velhas para } \\
\text { setores mais tranquilos porque somos mais } \\
\text { pacientes." }\end{array}$ & Helicônia & Operacional & Branca & Masculino & PCM45 \\
\hline $\begin{array}{l}\text { "A gente nota que alguns jovens não têm a mesma } \\
\text { paciência que os mais velhos [...]." }\end{array}$ & Begônia & Operacional & Branca & Masculino & PCM45 \\
\hline $\begin{array}{l}\text { "[...]a empresa dificulta a contratação de pessoas } \\
\text { com mais de } 45 \text { anos para algumas funções. Pensam } \\
\text { que eles são mais devagar, são mais lentos. A } \\
\text { pacificidade muitas vezes não é bem vista." }\end{array}$ & Jasmim & Administrativo & Branca & Feminino & PCM45 \\
\hline $\begin{array}{l}\text { O mercado de trabalho exclui pessoas com idade } \\
\text { acima de } 45 \text { anos [...]. Eu tive várias experiências } \\
\text { com colegas com mais de } 45 \text { anos que se } \\
\text { acomodaram na carreira." }\end{array}$ & Clúsia & Gestão & Branca & Masculino & - \\
\hline $\begin{array}{l}\text { "As empresas preferem contratar os mais novos } \\
\text { para a lida mais buta. Para quem trabalha em } \\
\text { escritório é um pouco mais fácil. Para quem } \\
\text { trabalha no 'bruto' é mais difícil" }\end{array}$ & Àlisson & Operacional & Branca & Masculino & PCM45 \\
\hline $\begin{array}{l}\text { "Na área onde eu atuo, passou dos } 45 \text { anos já é } \\
\text { considerado um idoso... Preferem muitas vezes } \\
\text { contratar } 3 \text { estagiários do que contratar uma pessoa } \\
\text { mais experiente [...]. As empresas consideram os } \\
\text { custos com assistência médica um ponto relevante } \\
\text { na contratação de pessoas mais velha [...]." }\end{array}$ & Begônia & Operacional & Branca & Masculino & PCM45 \\
\hline $\begin{array}{l}\text { "Sempre lidei em serviço pesado, só que agora o } \\
\text { corpo não aguenta mais. A terceira idade vem } \\
\text { chegando e a gente começa a sentir o cansaço..." }\end{array}$ & Helicônia & Operacional & Branca & Masculino & PCM45 \\
\hline
\end{tabular}

Fonte: Autores. 
Se, por um lado, é difícil para as pessoas com mais de 45 anos a manutenção do emprego, por outro lado, esse grupo etário encontra restrições para recolocação no mercado de trabalho, mesmo com vasta experiência profissional. Inegável, contudo, a dificuldade de recolocação após uma demissão. Especialmente para algumas funções.

Nota-se a partir das falas dos entrevistados (quadro 4) que o preconceito da idade (etarismo) começa a ceder espaço aos "quarentões", que até muito pouco tempo estavam relegados à espera do sistema previdenciário. Dessa maneira, frise-se às novas transformações da sociedade, as mudanças no tocante à empregabilidade em função do envelhecimento da população. Neste sentido, é preciso ter líderes bem preparados com conhecimento sobre gestão da diversidade. Contudo, e lamentavelmente, isso não é uma realidade para a maioria das organizações participantes deste estudo.

A despeito das possíveis limitações físicas decorrentes da idade, os aposentados entrevistados procuravam transmitir uma imagem de "aposentados ativos" ou "militantes", opondo-se "aos estigmas da inatividade, passividade e decrepitude associados à velhice".

\section{Considerações Finais}

Este estudo teve participação de $65 \%$ das organizações. Das organizações que não responderam à parte do questionário referente às principais características dos funcionários, alegaram dificuldade de identificar o perfil de seu pessoal. Talvez pela ausência de um censo interno e contínuo referente à diversidade entre seus dirigentes e empregados. Muitas organizações não têm dados claros sobre a diversidade de seu fluxo de talentos ou sua força de trabalho ao longo do tempo. Como resultado, eles não conseguem identificar com precisão os problemas ou iniciar intervenções direcionadas para resolvê-los.

De acordo com os levantamentos apresentados na análise quantitativa, o número de pessoas com deficiência é predominante entre a população não branca e feminina, sendo que as mulheres negras compõem a parte principal desse grupo. Por isso, além de cumprir a legislação, como a que prevê cotas para pessoas com deficiência, espera-se que as organizações promovam novas ações voluntárias direcionadas a essas pessoas, mas também aos outros públicos historicamente discriminados no mercado de trabalho, como mulheres e negros. A partir do levantamento qualitativo observa-se que maioria das organizações participantes desta pesquisa não tem ações afirmativas para incentivar a presença de diversidade em seus quadros. Quando tem, são em maior parcela ações pontuais, e não políticas com metas e ações planejadas. Grande parte das organizações tampouco desenvolve alguma política visando a promoção da igualdade de oportunidades entre homens e mulheres ou entre negros e brancos.

Observa-se que pessoas com mais de 45 anos têm sido tendência nas posições de comando nas organizações ijuienses. Parte dos empreendimentos localizados no município de Ijuí são administrados pelos próprios proprietários. A necessidade de ter mais de 45 anos, pelo menos, para atingir altos cargos ainda é uma inclinação entre as organizações aqui estudadas. Outrossim, permanece a figura do profissional velho de carteira para níveis de comando. O contraste ocorre em cargos que exigem esforços físicos e operacionais. Percebe-se ainda que a acessibilidade é a principal dificuldade encontrada por pessoas com deficiência ao ingressarem no mercado de trabalho, entre outras barreiras conceituais.

No geral, poucas organizações demonstram o interesse efetivo de ter diversidade nos candidatos que procuram a organização e na contratação. O estudo aponta que ainda são poucas as organizações que valorizam a diversidade e os princípios de igualdade de oportunidades e encoraja grupos vulneráveis à discriminação no mercado de trabalho a se candidatarem. Ainda tem muito a ser pesquisado sobre o tema. Este trabalho aponta para a necessidade de aprofundamento desta temática, dada sua relevância para promover novos desdobramentos no âmbito da "Gestão da Diversidade".

Neste contexto, o censo interno pode contribuir para criar políticas e ferramentas que facilitem o desenvolvimento da diversidade no ambiente corporativo. Contudo, é fundamental que os líderes organizacionais, ou seja, pessoas em cargos de gestão entendam esses vieses e não os deixem contaminar as suas decisões. Verifica-se a partir dos discursos dos sujeitos e no 
percurso teórico que gerenciar a diversidade constitui um grande desafio para os gerentes responsáveis pela responsabilidade de liderar equipes diversas.

Desta forma, sugestiona-se que estudos sobre as relações de individualidade e coletividade num ambiente diversificado possam contribuir para melhorar os resultados da diversidade no contexto organizacional. Ainda há poucas pesquisas direcionadas ao clima da diversidade e seus antecedentes, como liderança transformacional e comprometimento dos funcionários em um ambiente diverso. Também é aconselhável investigar os resultados organizacionais para confirmar as capacidades mediadoras do clima de diversidade. Estudos futuros devem explorar ainda mais a incorporação da diversidade a fim de verificar a incongruência entre o que é dito (a história que conta) e o que não é dito (a história verdadeira) em outras organizações.

\section{Referências}

Alves, M. A. \& Galeão-Silva, L. G. (2004). A crítica da gestão da diversidade nas organizações. Revista de Administração de Empresas, 44(3), https://doi.org/10.1590/S0034-75902004000300003.

Araújo, J. P. F. \& Antigo, M. F. (2015). Desemprego e qualificação da mão de obra no Brasil. Revista de Economia Contemporânea, 20 (2), 308-335, https://doi.org/10.1590/198055272025.

Austin, J. R. A (1997). Cognitive framework for understanding demographic influences in groups. International Journal of Organizational Analysis. 5(4), 342-59. https://doi.org/10.1108/eb028873.

Bahia M. S.; Schommer, P. C. \& Santos, E. M. (2008). Papéis e práticas empresariais para a inserção profissional de pessoas com deficiência: reflexões a partir de uma experiência. Enanpad - Pesquisa em Administração.

Barros, J. M. (2008). Cultura, diversidade e os desafios do desenvolvimento humano. In: Diversidade cultural: da proteção à promoção. Autêntica Editora.

Bento, M. A. S. (2000). Ação afirmativa e diversidade no trabalho. Casa do Psicólogo.

Burrel, G. \& Morgan G. (1979). Sociological paradigms and organizational analysis: elements of the sociology of corporate life. eBook Published (2017) London; Heinemann. https://doi.org/10.4324/9781315242804.

Chaves, L. G. M. (1971). Minorias e seu estudo no Brasil. Revista de Ciências Sociais, 1(1), 149-168. http://www.repositorio.ufc.br/handle/riufc/4487.

Cox, Jr. T \& Blake, S. (1991). Managing cultural diversity: implications for organizational competitiveness. Academy of Management Executive, 5 (3), https://doi.org/10.5465/ame.1991.4274465.

Cox, Jr. T. (1993). Cultural Diversity in Organizations: Theory, Research and Practice. Berrett-Koehler.

Esteves, S. (1999). Diversidade nas Organizações, uma Visão Atualizada. OIT//DIV. Brasília.

Fleury, M. (2000). Gerenciando a diversidade cultural: experiência de empresas brasileiras. Revista de Administração de Empresas, 40 (3), 18 -25. http://dx.doi.org/10.1590/S0034-75902000000300003.

Galeão-Silva, L. \& Alves, M. A. (2004). Crítica do Conceito de Diversidade nas Organizações. Revista de Administração de Empresas. http://dx.doi.org/10.1590/S0034-75902004000300003.

Gonçalves, E. B. P. et al. (2016). Gestão da diversidade: um estudo de gênero e raça em grandes empresas brasileiras. Enfoque.

Goulart, I. B., \& Coimbra, C. E. B. (2008). Inserção Profissional de Pessoas com Deficiência nas Empresas: responsabilidades, práticas e caminhos. Enanpad.

IBGE (2018). Síntese de indicadores sociais: uma análise das condições de vida da população brasileira. Coordenação de População e Indicadores Sociais. Rio de Janeiro: IBGE.

IBGE (2000). Instituto Brasileiro de Geografia e Estatística. Censo Demográfico 2000: Características gerais da população.

Instituto Ethos. (2000). Como as empresas podem (e devem) valorizar a diversidade. Instituto Ethos.

Instituto Ethos. (2016). Perfil social, racial e de gênero das 500 maiores empresas do Brasil e suas ações afirmativas / Instituto Ethos e Banco Interamericano de Desenvolvimento.

Instituto Ethos. (2002). Perfil social, racial e de gênero das diretorias das grandes empresas brasileiras. Ethos.

Lancillotti, S. S. P. (2003). Deficiência e trabalho: redimensionando o singular no contexto universal.

LeBreton, D. (1970). Adeus ao corpo: antropologia e sociedade. Papirus. 
Research, Society and Development, v. 10, n. 12, e432101220701, 2021

(CC BY 4.0) | ISSN 2525-3409 | DOI: http://dx.doi.org/10.33448/rsd-v10i12.20701

Mckay, P. F \& Avery, D. R. (2015). "Diversity Climate in Organizations: Current Wisdom and Domains of Incertainty, (33), 191-233, Emerald Group Publishing Limited, Bingley. https://doi.org/10.1108/S0742-730120150000033008.

Malik, A. R \& Singh, P. (2017). “Transformational leadership and cultural minorities: a conceptual model”. European Business Review, 29 (5), $500-514$. https://doi.org/10.1108/EBR-12-2015-0181.

Mendes, R. H. (2004). Oportunidades e Desafios da Diversidade. ERA Executivo, 3 (2).

Milliken, F. J. \& Martins, L. L (1996). Procurando para Tópicos comuns: Entendimento a múltiplos efeitos de diversidade em grupos organizacionais.

Moreira, A. (1984). Poder funcional - poder errático: política internacional de minorias e comunidades. Jornadas de Tropicologia.

Motta, F. C. P. (1996). Cultura e organizações no Brasil. NPP - Núcleo de Pesquisas e Publicações Série Relatórios de Pesquisa.

Munanga K. (2004). Uma abordagem conceitual das noções de raça, racismo, identidade e etnia [Internet]. In: Programa de educação sobre o negro na sociedade brasileira. EDUFF.

Munanga, K. (2006). Algumas considerações sobre "raça", ação afirmativa e identidade negra no Brasil: Fundamentos Antropológicos. Revista USP, (68), 4657, https://doi.org/10.11606/issn.2316-9036.v0i68p46-57.

Nogueira, O. (1979). Tanto preto quanto branco: estudos de relações raciais. T. A. Queiroz.

Nkomo, S. M. \& Cox Jr, T. (1999). Diversidade e identidade nas organizações. In: Clegg, S.; Hardy, C.; Nord, W. Handbook de estudos organizacionais. São Paulo: Atlas.

Oliveira. N. H. D. (2009). Recomeçar: família, filhos e desafios. Editora UNESP: Cultura Acadêmica. https://doi.org/10.7476/9788579830365

Organização Internacional do Trabalho. (2002). Diversidade-Avanço Conceitual para a Educação Profissional e o Trabalho - Ensaios e Reflexões. OIT.

Pereira, J. B. B. (1996). Racismo à brasileira. In: Munanga, Kabengele (Org.). Estratégias e políticas de combate à discriminação racial. EDUSP.

Pereira, A. C. C \& Passerino, L. M. (2018). Soluções assistivas para inclusão no mercado de trabalho: estudo de caso espanhol. Congresso Brasileiro de Educação Especial (CBEE).

Pereira, O. M. L. (2012). A dor da cor: Reflexões sobre o papel do negro no Brasil. Cadernos Imbondeiro.

Ribeiro, M. A \& Carneiro, R. (2009). A inclusão indesejada: as empresas brasileiras face à lei de cotas para pessoas com deficiência no mercado de trabalho. Organizações \& Sociedade, 16 (50) 545-64.

Robbins, S., \& Coulter, M. (1998) Administração. Prentice-Hall do Brasil.

Saraiva L. A. S. \& Irigaray, H. A. R. (2009). Políticas de diversidade nas organizações: uma questão de discurso? Revista de Administração de Empresas, 9 (3), 337-348. http://dx.doi.org/10.1590/S0034-75902009000300008.

Suzano, J. C. C. et al. (2014) Análise da produção acadêmica nacional dos últimos 20 anos sobre a inserção de pessoa portadora de deficiência no mercado de trabalho. In: Carvalho-Freitas, M. N. \& Marques, A. L. (Org.). O trabalho e as pessoas com deficiência: pesquisas, práticas e instrumentos de diagnóstico.

Yin, R. K. (2001). Estudo de caso: planejamento e métodos. (2a ed.), Bookman.

Wise, L. R. \& Tschirhart, M. (2002). Examining empirical evidence on diversity effects: how useful is diversity research for public-sector managers? Public Administration Review, 60 (5), 386-95. https://doi.org/10.1111/0033-3352.00102. 